\title{
Diário do Mestre Francisco Fernandes
}

\author{
Georg Lachnitt ${ }^{1}$
}

DOI: http://dx.doi.org/10.20435/tellus.v17i33.476

\section{APRESENTAÇÃO}

Francisco Fernandes Sanchez nasceu em Bejar, na Espanha, aos 04 de abril de 1891. Nessa cidade natal, frequentou o colégio salesiano e, em 1919, entrou no noviciado para se fazer salesiano. Optou pela vida salesiana laical. Era de uma inteligência avantajada e isso se mostrou, sobretudo, pela sua facilidade em escrever artigos dos mais diversos.

Em 1922 segue seus ideais missionários, rumando para as Missões de Mato Grosso. Depois de uma decepção, fica um ano em Corumbá e segue no ano seguinte para Merúri. Professor na escola, maestro de música, meteorologista e agricultor, eis suas atividades. Procurando, em sentido missionário, um campo mais compromissado, oferece-se para integrar o grupo de aproximação dos terríveis índios Xavante, grupo este chefiado pelo Pe. Hipólito Chovelon. Corre o ano de 1937. Com sua facilidade de escrever, acompanhou essa expedição, registrando em diário toda a aventura. Temos assim detalhes peculiares que não constam nos relatórios oficiais do Pe. Chovelon.

Em 1950 integra a comunidade de Xavantina, junto ao Pe. Colbacchini e Pe. Pedro Sbardellotto, onde novamente dirigem seus esforços à aproximação e pacificação dos Xavante. Nisso lhe foram úteis seus conhecimentos rudimentares da língua Xerente. Este contato bem sucedido deu-se aos 29 de janeiro de 1951.

Em 1955 destina-se à nova comunidade missionária entre os Xavante na missão de Santa Terezinha. Faz de tudo ao seu alcance para a concretização da atividade missionária naquela situação pioneira. Tem facilidade de se integrar entre os índios e assim estabelecer um diálogo proveitoso.

Tendo sido abandonada aquela missão, ele continua, em Sangradouro, suas atividades entre os Xavante que para lá se dirigiram em 1956.

${ }^{1}$ Universidade Católica Dom Bosco, Campo Grande, Mato Grosso do Sul, Brasil. 
Lá o encontrei em 1972 com suas limitações, por sua saúde enfraquecida, mas assistido com muita dedicação por vários Xavante. A surdez Ihe limitou muito a comunicação, mas fato é que os meninos Xavante que não falavam português, o entendiam e lhe passavam as notícias.

Em 1974, como a saúde dele exigiu melhores cuidados, foi transferido para Coxipó da Ponte, onde, longe dos Xavante, chegou a falecer aos 23 de dezembro de 1977, com 86 anos de idade. ${ }^{2}$

Pe. Georg Lachnitt

\section{DESCRIÇÃO E PLANO DO MANUSCRITO}

O texto manuscrito, da autoria do Mestre Francisco Fernandes, está em caderno espiral, quadriculado com as folhas já amareladas pelo tempo. É de capa de papelão de cor cinza na frente, 225×155 mm, e desprovido de capa após a última folha. A numeração, feita pelo autor do manuscrito e o caderno, começa na página 21 e vai até a página 64. Os números estão no canto superior esquerdo da página. Apenas a frente da página é numerada, o verso não. $\mathrm{Na}$ transcrição eu numero o verso para facilitar sua identificação no manuscrito. $\mathrm{O}$ texto vai da página 21 à página 43. As demais páginas estão em branco. A página 43 está solta; a tinta é violácea de caneta esferográfica. A caligrafia é miúda e bastante legível.

O "Plano" é deduzido pela leitura do manuscrito, os títulos são do autor, eu apenas os numerei de 1 a 6 .

O título que o autor dá ao seu relato É: "Aventuras Xavantecas da Missão Salesiana de Mato Grosso no Rio das Mortes".

Início do manuscrito, p. 21 até a p. 33v (=verso)

\section{INTRODUÇÃO}

1. Aventura do massacre do filho de Raimundão Pereira.

2. Como a fazenda feliz do Sr. Franklin ficou triste.

\footnotetext{
2 Estas informações foram tiradas da "Carta Mortuária" escrita pelo Pe. José Corazza, aos 10 de março de 1978.
} 
3. Os verdadeiros pastores dão a vida por suas ovelhas.

4. 1 ㅇ encontro amistoso no ano de 1937

5. Descrição da 2a expedição - 1938 - da qual tomei parte apesar dos repetidos ataques de malária.

Desloquei para o final deste arquivo a nota (1) que está na última página do manuscrito (p. 43) para facilitar o entendimento do texto.

6. Encontro com dois grupos de Xavante em Xavantina em 1951.

Pe. João Bosco Monteiro Maciel

\section{Sobre o autor:}

Georg Lachnitt: Salesiano, diretor do Núcleo de Estudos e Pesquisas das Populações Indígenas (Neppi/UCDB), responsável pelo Centro de Documentação Indígena da UCDB e Editor da Revista Tellus. E-mail: lachnitt@ucdb.br

Recebido em 2 de fevereiro de 2017

Aprovado para publicação em 15 de maio 2017 
